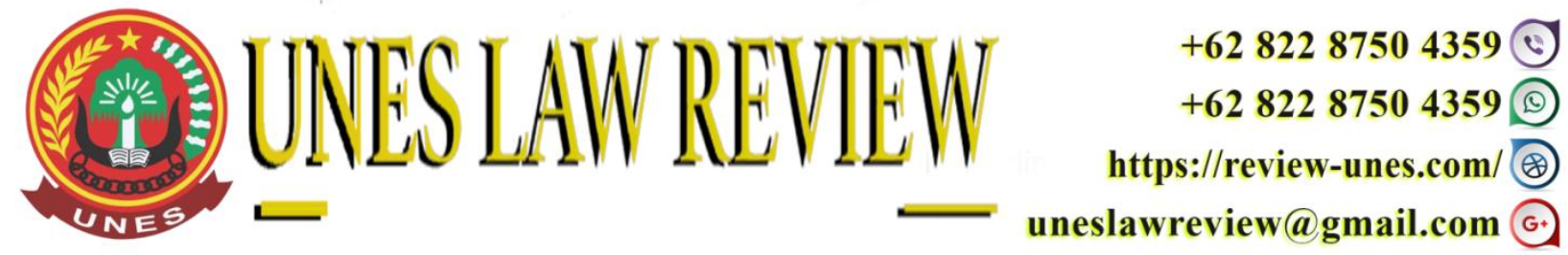

DOI: https://doi.org/10.31933/unesrev.v3i2

Diterima: 14/01/2021, Diperbaiki: 20/01/2021, Diterbitkan: 20/02/2021

\title{
FUNGSI DIGITAL FORENSIK BAGI SATRESKRIM POLRES AGAM DALAM PENYIDIKAN TINDAK PIDANA JUDI ONLINE
}

\author{
Algino Ganaro \\ Program Magister Ilmu Hukum, Universitas Ekasakti, Padang, Indonesia \\ Email: alginoganaro75@gmail.com \\ Corresponding Author: Algino
}

\section{ABSTRACT}

The function of Digital Forensics in Online Gambling Crime Investigation by the Agam Police Criminal Investigation Unit is to obtain evidence of an online gambling crime by knowing who did it, what was done, what software was used, what process results were used and when to do it . In online gambling crimes that occur in the jurisdiction of the Agam Police, evidence collected through digital forensics is in the form of information on gambling crimes carried out by examining sites that are used as a means or place for gambling. Constraints in Using Digital Forensics in Online Gambling Crime Investigation By Satreskrim Agam Police is the address of most online gambling websites located abroad and made by foreign countries, bank accounts are always changing. The application data for opening a bank account that is used to accept online gambling transactions is fictitious, evidence is easy to change and is lost, the high level of knowledge of the actors about information technology and the lack of public awareness and concern for online gambling.

Kata Kunci: Judi Online, Penyidikan, Digital forensik

\section{PENDAHULUAN}

Berkembangnya teknologi informasi dan komunikasi yang sedemikian rupa, dunia telah memasuki era baru komunikasi, yang telah menyebabkan dunia menjadi tanpa batas (borderless) yang dimana terjadinya percepatan globalisasi dan lompatan besar bagi penyebaran informasi dan komunikasi seluruh dunia.

Revolusi teknologi informasi dan komunikasi berawal sejak ditemukannya komputer yang dalam perkembangannya menciptakan suatu dunia tersendiri yang lazim disebut dengan dunia maya (cyberspace) yang menjadi bagian dari berbagai penemuan di bidang teknologi informasi dan komunikasi yang saat ini memungkinkan orang untuk menggunakan jaringan internet melalui komputer pribadi (personal computer /PC) atau media elektronik lainnya di manapun. 
Perkembangan teknologi informasi dan komunikasi itu berpadu dengan media dan komputer, yang kemudian melahirkan jaringan komputer yang sering kita sebut dengan istilah internet. Kemajuan-kemajuan di bidang teknologi informasi dan komunikasi tersebut juga diikuti dengan dampak negatif yang mengancam dan membahayakan manusia. Seiring dengan kemajuan tersebut, ternyata teknologi informasi yang berkembang dalam jaringan internet juga menyebabkan terjadinya kejahatan pada dunia internet itu sendiri. Dimana teknologi tersebut sekaligus dapat juga digunakan untuk menciptakan atau menjadi sarana efektif bagi terjadinya perbuatan perbuatan melawan hukum atau tindak pidana. Dengan terjadinya perbuatan melawan hukum tersebut, maka ruang lingkup hukum harus diperluas untuk dapat menjangkau perbuatanperbuatan tersebut.

Teknologi dan hukum merupakan dua unsur yang saling mempengaruhi dan keduannya juga mempengaruhi masyarakat. Heidegger berpendapat bahwa di satu sisi teknologi dapat dilihat sebagai sarana untuk mencapai tujuan tertentu. Akan tetapi, di sisi lain teknologi juga dapat dilihat sebagai aktivitas manusiawi. Pada dasarnya, setiap teknologi dikembangkan untuk memenuhi kebutuhan tertentu dan melalui teknologi itu diberikan suatu manfaat dan layanan bagi manusia termasuk meningkatkan keefisienan dan keefektivitasan kerja.

Proses pembuktian suatu alat bukti yang berupa data digital menyangkut aspek validasi data digital yang dijadikan alat bukti tersebut. Aspek lain yang mempersulit proses pembuktian ini adalah masalah menghadirkan alat bukti tersebut, apakah dihadirkan cukup dengan perangkat lunaknya (software) ataukah harus dengan perangkat kerasnya (hardware).

Seringkali penegak hukum di Indonesia mengalami kesulitan saat menjerat pelaku karena asalan pembuktian (documentary evidence) yang tidak memenuhi ketentuan sistem hukum pidana Indonesia. Sementara upaya penjeratan terhadap pelaku-pelaku kejahatan mayantara (cybercrime) harus tetap dilakukan, upaya perluasan alat bukti menjadi solusi untuk menegakkan hukum.

Pencarian bukti-bukti digital untuk menjerat pelaku perjudian secara on line seringkali merupakan pekerjaan yang sangat kompleks dimana dalam proses digital forensik yang dilakukan oleh seorang digital forensik analis/investigator harus mengikuti prosedur-prosedur yang diakui secara hukum baik nasional maupun internasional, termasuk juga mereka harus memahami secara teoritis hal-hal yang berkaitan dengan bukti digital yang ditemukan, disamping juga memahami bagaimana penggunaan software-software forensik untuk mencari bukti-bukti digital tersebut dengan benar. Sering kali juga bukti-bukti digital tersebut sudah dihapus oleh pelaku untuk menghilangkan jejaknya. Di sinilah tantangan bagi seorang analis/investigator untuk menelusuri kembali bukti digital yang sudah hilang tersebut, bahkan mereka harus mampu untuk me-recover-nya kembali.

Berdasarkan latar belakang pemikiran di atas, maka permasalahan adalah fungsi dan kendala penggunaan digital forensik dalam penyidikan tindak pidana judi online oleh Satreskrim Polres Agam. 


\section{METODE PENELITIAN}

Spesifikasi penelitian adalah deskriptif analitis, dengan metode pendekatan yuridis normative didukung oleh yuridis empiris. Jenis data yang digunakan adalah data sekunder. Data sekunder diperoleh dari studi dokumen dan studi kepustakaan. Data yang diperoleh kemudian dianalisa secara kualitatif .

\section{HASIL DAN PEMBAHASAN}

\section{Fungsi Digital Forensik Dalam Penyidikan Tindak Pidana Judi Online Oleh Satreskrim Polres Agam}

Forensik merupakan suatu kegiatan untuk melakukan investigasi dan menetapkan fakta yang berhubungan dengan suatu tindak kriminal dan permasalahan hukum lainnya. Sedangkan digital forensik merupakan bagian dari ilmu forensik yang melingkupi penemuan dan investigasi materi (data) yang temukan pada perangkat digital seperti; komputer, handphone, tablet, PDA, networking devices, dan sejenisnya.

Pada penyidikan yang dilakukan Satreskrim Polres Agam Apabila ahli yang dihadirkan di dalam menjalankan Digital Forensic tidak melalui ketiga tahapan tersebut, maka keterangan ahli tersebut harus dikesampingkan karena pelaksanaan Digital Forensic tidak sesuai dengan tahapan yang seharusnya karena apabila Digital Forensic tidak dilakukan dengan mengikuti ketiga tahapan tersebut di atas, hasil data image file yang tidak identik dengan data asal karena dimungkinkan terjadi penambahan, pengurangan atau penghapusan data asal.

Pada tindak pidana judi online yang terjadi di wilayah hukum Polres Agam, alat bukti yang dikumpulkan melalui digital forensik adalah berupa informasi tindak pidana perjudian yang dilakukan dengan memeriksa situs yang digunakan sebagai sarana atau tempat melakukan perjudian. Dimana perjudian dilakukan dengan cara membuka situs online pada website : http://shio12.com/main/ Kemudian mengisi beranda / tampilan masuk dengan USERNAME : Rojer, setelah itu PASSWORD : Rojer1. Setelah situs dapat dibuka Kemudian dimasukan angka yang ada disamping tampilan kedalam kolom kosong lalu tekan masuk di beranda setelah beberapa waktu kemudian baru masuk dalam web site 12Shio1. Pada web site 12Shio1 akan ditemui beranda atas 4D dan kemudian masuk di 4D kemudian keluar di beranda website GAMES 4D itu dan disitulah lalu dimasukan angka angka pasangan togel dan dibaris dimasukan jumlah pasangan terhadap angka angka pasangan Togel Online tersebut. Pemeriksaan terhadap situs yang digunakan ini dan terhadap cara melakukan perjudian dilakukan oleh seorang ahli forensik.

Pada Tindak pidana judi online yang lain dengan tersangka Doni, dilakukan dengan mempergunakan perangkat Hand phone dan Wifi melalui website : http://www.12ratu.com/main/?. Permainan judi jenis_togel online adalah dengan cara_membuka situs online dengan website : http://www.12ratu.com/main/? Kemudian mengisi beranda / tampilan masuk dengan USERNAME : Hoki60, setelah itu PASSWORD : Dosa16. Kemudian memasukan angka yang ada disamping tampilan kedalam kolom kosong setelah itu ditekan masuk meranda .setelah beberapa waktu kemudian ianya DONI SAPUTRA Pgl DONI baru 
masuk dalam websaite 12 Shio 3 , disana kita menemui dimeranda atas 4D dan masuk di 4D kemudian keluar dimeranda website GAMES 4D itu merupakan togel online dan terdapat kolom kolom angka kosong yang akan di pasang dan uang pasang baris keduanya. Tersangka memasang pada malam hari dengan batas waktu pukul 22.00 wib itu merupakan togel jenis Hongkong sedangkan jika memasang siang hari dengan batas waktu pukul 17.00 wib itu merupakan togel jenis singapur, Syaratnya mempunyai account untuk masuk dalam website http://www.12ratu.com/main/ agar dapat melakukan permainan judi jenis togel online tersebut adalah harus mempunyai email dan nomor rekening untuk deposit dan email yang dia miliki yaitu a.hasdel@yahoo.com dengan Nomor Rekening BRI 787301004482531 atas nama doni saputra. Telah membuat acount di situs tersebut sebagai suatu persyaratan untuk bergabung dalam aktifitas website tersebut dimana tersangka mendaftarkan nomor rekening sehingga nomor rekening tersebut dapat memasukan dan menarik deposit dari situs sehingga bisa juga dicairkan melalui ATM tunai. Pemeriksaan digital forensic dilakukan terhadap situs web yang digunakan dan nomor rekening dari tersangka.

Penyidik memerlukan waktu yang sangat lama karena para pelaku judi online melalui website menggunakan IP Proxy (pengalihan IP sebenarnya) sehingga petugas kesulitan untuk mencari keberadaan website judi online tersebut. Lain halnya dengan judi online yang menggunakan sarana SMS pada handphone, yang mana bandar judi online tersebut mengedarkan judi onlinenya melalui sms sehingga untuk kasus seperti yang terjadi di wilayah hukum Polres Agam, oleh petugas masih bisa dilakukan penyelidikan hingga penyidikan.

Guna mengungkap Tindak pidana judi online, pihak penyidik Satreskrim Polres Agam memerlukan barang bukti sebagai alat untuk memperkuat tindak pidana yang dilakukan oleh para pelaku. Berdasarkan hasil wawancara yang dilakukan, cara yang digunakan penyidik untuk memperoleh barang bukti tindak pidana judi online, adalah dengan memetakan terhadap apa saja media Informasi dan Transaksi Elektronik yang digunakan oleh pelaku judi online. Sehingga pada saat petugas melakukan upaya penangkapan, penggeledahan, dan penyitaan terhadap pelaku judi online, petugas dengan cepat mengamankan barang bukti media Informasi dan Transaksi Elektronik, dikarenakan untuk proses mengamankan barang bukti media Informasi dan Transaksi Elektronik, dibutuhkan kecepatan dan kehati-hatian dengan alasan barang bukti media Informasi dan Transaksi Elektronik dapat dengan mudah dihilangkan atau dirubah oleh pelaku judi online tersebut.

\section{Kendala Dalam Penggunaan Digital Forensik Dalam Penyidikan Tindak Pidana Judi Online Oleh Satreskrim Polres Agam.}

Masalah mengenai tindak pidana perjudian secara online sulit untuk ditanggulangi maupun untuk ditegakkan, karena memerlukan waktu yang cukup lama dan sulitnya melakukan penyelidikan terhadap tindak pidana perjudian secara online tersebut. Pihak kepolisian menyadari betapa sulitnya menjangkau pelaku judi online, termasuk mencegah masuknya berbagai website atau situs yang bermuatan perjudian, hal tersebut disebabkan karena penegakan 
hukum terkait perjudian secara online membutuhkan kepakaran cyber dan dana yang sangat besar.

Banyak hambatan maupun kendala yang muncul pada saat kepolisian melakukan penegakan hukum terhadap tindak pidana perjudian secara online. Hambatan dan kendala sebagai berikut yang membuat sulitnya pihak kepolisian melakukan penegakan hukum:

1. Ip addres public website permainan judi alokasi berada diluar negeri.

Alamat website judi online kebanyakan berada diluar negeri dan dibuat oleh luar negeri, akan mempersulit penyelidikan apabila ada perbedaan pandangan hukum antara negara Indonesia dengan negara lain, karena kemungkinan negara di mana tempat pembuatan website tersebut, judi dianggap sah atau legal.

2. Perbedaan pandangan hukum.

Adanya perbedaan pandangan hukum negara Republik Indonesia dengan negara tempat penyedia server website judi online, di negara Indonesia judi termasuk salah satu tindak pidana, akan tetapi di luar negeri belum tentu judi termasuk sebagai tindak pidana, sehingga apabila terjadi hal seperti itu negara sebagai tempat penyedia server website judi online melegalkan judi, maka negara tersebut tidak akan mau untuk memberikan data terkait judi online tersebut.

Perbedaan pandangan hukum ini berkaitan dengan teori Legal System Lawrence M Friedman mengenai unsur-unsur sistem hukum yang dapat mempengaruhi penegakan hukum. Perbedaan pandangan hukum menjadi bagian dari substansi hukum (subtance of the law). Dimana substansi hukum ini sangat mempengaruhi upaya penegakan hukum yang dilakukan oleh aparat penegak hukum. Perbedaan pandangan hukum ini menjadi salah satu hambatan aparat kepolisian karena pandangan hukum Indonesia dengan negara luar negeri sangatlah berbeda apabila peraturan mengenai judi online ini tidak diatur di luar negeri (legal). Substansi hukum juga dapat menentukan bisa atau tidaknya sebuah hukum itu dilaksanakan.

3. Rekening bank selalu berganti-ganti.

Rekening bank yang digunakan oleh para pelaku untuk menerima transaksi judi online tersebut selalu berganti-ganti, para pelaku judi online ini mempunyai banyak rekening bank dengan identitas yang berbeda-beda dan bank yang berbeda beda.

4. Data aplikasi pembukaan rekening bank yang digunakan untuk menerima transaksi judi online tersebut fiktif.

Data dan identitas yang digunakan oleh pelaku untuk membuat rekening bank menggunakan identitas palsu, sehingga pihak kepolisian menjadi kesulitan untuk menemukan pelaku judi online tersebut.

5. Barang bukti mudah dirubah dan hilang.

Barang bukti untuk judi online ini merupakan barang bukti media Informasi dan Transaksi Elektronik dapat dengan mudah dihilangkanatau dirubah oleh pelaku judi online tersebut, sehingga perlu kecapatan dan kehati-hatian untuk mengamankan barang bukti.

6. Kurangnya jumlah personil yang ahli dalam melakukan penanganan/penyidikan dengan menggunakan digital forensik pada tindak pidana perjudian secara online. Hal demikian 
dapat dirasakan seperti apabila kejahatan yang terjadi aparat penegak hukumnya belum siap bahkan tidak mampu (gagap teknologi) untuk mengusut pelakunya dan alat-alat bukti yang dipergunakan dalam hubungannya dengan bentuk kejahatan ini sulit terdeksi.

7. Kurangnya anggaran ataupun kemampuan keuangan negara;

Apabila akan dikembangkan sampai Polres, unit yang menangani masalah cyber ini membutuhkan banyak dana, dan anggaran yang cukup banyak karena sarana dan prasarana yang digunakan menggunakan teknologi yang canggih untuk dapat mengungkap cyber crime baik itu untuk menyelidiki maupun untuk melakukan penyidikan.

8. Tingginya tingkat pengetahuan para pelaku terhadap teknologi informasi.

Para pelaku perjudian online pasti sudah memahami atau menguasai ilmu teknologi informasi, sehingga hal tersebut dapat dilakukan para pelaku untuk mengelabuhi petugas agar sulit untuk ditemukan. Terkadang ilmu teknologi informasi yang kuasai oleh petugas sangat jauh sedikit dibandingkan para pelaku cybercrime. Kebanyakan para pelaku judi online merupakan orangyang sudah sangat berpengalaman dalam bidang teknologi informasi.

9. Kurangnya kesadaran dan kepedulian masyarakat.

Masyarakat kurang peduli terhadap perjudian secara online, masyarakat seakan acuh terhadap tindak pidana perjudian online, mereka banyak menganggap perjudian adalah hal biasa. Hal tersebutlah yang dapat menghambat aparat penegak hukum dalam melakukan upaya penegakan hukum terhadap tindak pidana perjudian secara online, karena masyarakat kurang peduli dan sadar untuk membantu aparat penegak hukum mengungkap perjudian online tersebut. Masyarakat juga seakan-akan menutupi apabila mengetahui perjudian di lingkungannya. Apabila dikaji dari teori Legal System Lawrence M. Friedman, kurangnya kesadaran dan kepedulian masyarakat berkaitan dengan unsur budaya hukum (legal culture).

Apabila masyarakat kurang sadar dalam mematuhi hukum atau suatu peraturan yang ada, maka masyarakat tidak dapat mendukung dan mendorong upaya penegakan hukum terhadap tindak pidana perjudian secara online, dan apabila masyarakat tidak bisa mematuhi hukum atau peraturan dan tidak membantu aparat penegak hukum, atau apabila masyarakat bersifat acuh dengan perjudian online dan menganggap perjudian online sebagai perbuatan biasa, maka masyarakat akan menjadi pengahambat utama pada penegakan hukum terhadap tindak pidana perjudian secara online.

\section{PENUTUP}

Di wilayah hukum Polres Agam, alat bukti yang dikumpulkan melalui digital forensik adalah berupa informasi tindak pidana perjudian yang dilakukan dengan memeriksa situs yang digunakan sebagai sarana atau tempat melakukan perjudian. Alat bukti selanjutnya adalah alat bukti petunjuk yang juga terdapat dalam media elektronik dan harus diperiksa dengan cara digital forensik.

\section{DAFTAR PUSTAKA}

Duwi Priyanto, Belajar Mudah Internet, Mediakom, Yogyakarta, 2009 
Sigid Suseno, Yuridiksi Tindak Pidana Siber, Refika Aditama, Bandung, 2012

Budi Suhariyanto, Tindak Pidana Teknologi Informasi (Cyber Crime) :Urgensi Pengaturan dan celah Hukumnya, Rajawali Press, Jakarta, 2013

Josua Sitompul, Cyberspace, Cybercrimes, Cyberlaw : Tinjauan Aspek Hukum Pidana, Tatanusa, Jakarta, 2012

R.Subekti, Hukum Pembuktian, Pradnya Paramita, Jakarta, 1995

Dikdik M.Arief Mansur dan Elisatris Gultom, Cyber Law-Aspek Hukum Teknologi Informasi, Refika Aditama, Bandung, 2005

Muhammad Nuh Al-Azhar, Digital Forensic : Panduan Praktis Investigasi Komputer, Salemba Infotek, Jakarta, 2012

Budi Raharjo, 2013, Sekilas Mengenai Forensik Digital, Jurnal Sosioteknologi, diambil dari budi.raharjo.id, 